\title{
Cumhuriyet Düşüncesi İle İlgili Gelişmeler ve Cumhuriyetin İlanına Yönelik Tepkiler
}

\author{
İbrahim İnci a, b
}

\section{Özet}

Cumhuriyet milletin egemenliğini elinde tuttuğu ve bunu temsilcileri aracılığıyla kullandığı siyasal sistemdir. Milli Mücadele yıllarına kadar milli egemenlik kavramına cumhuriyet anlamı yüklenmemiştir. Bu yıllarda bağımsızlığı ve vatanın kurtuluşunu sağlamak amacıyla düzenlenen bölgesel ve ulusal kongrelerin kurduğu siyasal iktidarlar birer cumhuriyet hükümetleri idi. Gücünü doğrudan halktan alan bu yönetimler hem vatanı düşmana karşı savunmuşlar hem de cumhuriyet düşüncesinin gelişmesini sağlamışlardır. Türkiye Büyük Millet Meclisi açıldığı günden itibaren adı koyulmamış demokratik bir cumhuriyet rejimine sahipti. Atatürk'ün önderliğinde kurulan yeni Türk devletinin bu demokratik niteliği 1921 Anayasası ile pekişmiştir. Saltanatın kaldırılması ile cumhuriyetin önündeki büyük bir engel aşılmıştır. Ekim 1923'te cumhuriyetin ilanı aslında üç yıldır yürürlükte olan rejimin adını koymak anlamına gelmektedir. Cumhuriyetin ilanına yönelik tepkiler, farklı bir rejim talebinden ziyade cumhuriyetin ilanının aceleye getirilmiş olmasına ve cumhuriyetin niteliğine yönelikti. Tepkilerin temel nedeni, cumhuriyetle birlikte sistemde yapılan değişikliğin rejimin demokratik niteliğini zayıflatması endişesiydi.
Anahtar Kelimeler

Ulus

Meclis

Egemenlik

Cumhuriyet

Makale Hakkında

Geliş Tarihi: 29.07.2019

Kabul Tarihi: 20.11.2019

Doi: 10.18026/cbayarsos.595868

\section{The Developments About the Republican Idea and Reactions Towards the Decleration of the Republic}

\begin{abstract}
Republic is a regime in which people rule through their representatives. Until the Independence War of 1919-1922, national sovereignty did not mean republic in Turkey. During this period, political structure that regional and national congresses formed was indeed a republic like governments, deriving their power from people. These governments both fought against the enemies of the motherland and contributed to the development of the idea of republic. Turkish National Assembly had a democratic republican government since the very beginning even though it was not called so. This democratic character of the new Turkish state was strengthened with the Constitution of 1921. With the Abolition of the Sultanate, the last obstacle to the republic was removed. The promulgation of the republic on 29 October 1923 was basically naming the existing republican regime.
\end{abstract}

\begin{tabular}{r} 
Keywords \\
\hline Nation \\
Assembly \\
Sovereignty \\
Republic \\
About Article \\
\hline Received: 29.07 .2019 \\
Accepted: 20.11 .2019 \\
Doi: $10.18026 /$ cbayarsos.595868
\end{tabular}

Doi: 10.18026/cbayarsos.595868

\footnotetext{
a İletişim Yazarı: ibrhminci@hotmail.com

b Doç. Dr., Manisa Celal Bayar Üniversitesi Fen Edebiyat Fakültesi Tarih Bölümü, ORCID: 0000-0002-1357-6549
} 


\section{Giriş}

"Cumhuriyet" kelimesi Arapça "cumhur" kelimesinden türetilmiştir. "Cumhur" halk anlamına gelmektedir. "Cumhuri' ise, cumhura, yani "millete, halka mahsus" anlamındadır (Devellioğlu, 1984: 77). Etimolojik olarak cumhuriyeti "halka mahsus şey", "halka ait olan şey" diye tanımlamak gerekir (Başgil,1960:344). Buna göre, etimolojik olarak, devlet şekli anlamında "cumhuriyet", "halka ait olan devlet" diye tarif edilebilir (Gözler, 1999: 52)

Cumhuriyet sözcügünün hukuk sözlügündeki anlamı, devlet reisi, millet veya millet meclisleri tarafından yönetilen hükümet şeklidir. Cumhuriyetçilik ise, milli hâkimiyet idealinin en iyi ve en güvenli surette temsil ve uygulanmasına elverişli, hükümet biçimi olduğunu kabul etmektir (Türk Hukuk Lügatı, 1944: 56).

Cumhuriyet kelimesi Fransizcada "republique" kelimesi ile ifade edilmektedir. Bu kelime "şey", "mal" anlamına gelen Latince res ve "kamu", "halk" anlamına gelen publica kelimelerinden türemiştir. Latince res publica "kamu malı' halkın malı" demektir. Devlet şekli anlaminda respublica (republique) ise, "halkın malı olan devlet" olarak tanımlanabilir. Bu tanımlamalardan da anlaşıldığı üzere, Türkçe "cumhuriyet" ve Fransızca "republique" kavramları aynı anlama gelmektedirler (Gözler, 1999: 52).

Cumhuriyet rejimi en üstün otorite olarak halkı kabul eder. Devleti yönetme hakkı halkın elinde bulunmaktadır. Cumhuriyet hükümetlerinde yöneticiler, kamunun iradesini ve çıkarlarını daima göz önünde bulundurmak zorundadırlar. Halk kendini yönetecekleri kendisi istediği gibi seçebilir, denetleyebilir ve belli aralıklarla değiştirebilir.

Cumhuriyet rejiminde ana kural seçimdir. Cumhuriyeti monarşiden ayıran en belirgin fark, devlet hizmetlerinin hepsinde veraset usulünü mutlak surette reddetmesi, bunun yerine seçim ve tayin usulünü koymasıdır.

Atatürk'e göre; "demokrasi prensibinin en asrî ve en mantıkî tatbikini temin eden hükümet şekli, cumhuriyettir" (İnan, 2000: 44,53; Güner, 2006: 42).

Türkiye'de Cumhuriyetin ilanı sürecinde yaşanan tartışmalara 1şık tutacağını düşündüğümüzden yönetim biçimleri hakkında bilgi vermek yararlı olacaktır. Montesquieu rejimleri üçe ayırmaktadır; cumhuriyet, monarşi ve despotizm. Bu konuda Kanunların Ruhu adlı eserinde şunları kaydetmektedir: Cumhuriyet, milletin tamamının ya da bir parçasının yönetimi elinde bulundurmasıdır. Monarşi ise bir kişinin sabit ve yerleşmiş yasalarla yönetimidir. Despotizm ise, bir kişinin hiçbir yasa ve kurala bağlı olmadan kendi istek ve heveslerine göre ülkeyi yönetmesidir (Montesquieu, 2011: 28).

J. J. Rousseau ise hükümet biçimlerini demokrasi, aristokrasi ve monarşi olmak üzere üç farlı kategoriye ayırmıştır. Demokraside yasayı yapan ve uygulayan egemenliği elinde bulunduran toplumun salt çoğunluğudur. Aristokraside ise yöneticilerin sayısı yönetilenlere oranla daha azdır. Bu hükümet şeklinde yönetim görevi bir azınlığa bırakılmıştır. Monarşide ise egemen güç kanunları yapar ve tek kişi yasalara göre hükümeti yönetir (Rousseau, 2006: 61).

Günümüzde bir yönetim biçimi olarak aristokrasi artık tarihe intikal etmiştir. Siyaset bilimciler 20. yüzyıl başlarından bu yana yönetim biçimlerini monarşi ve cumhuriyet olarak iki kategoride incelemektedirler (Gözler, 1999: 53).

Mutlakıyet, despotizm, demokratiklik gibi unsurlar monarşiyi veya cumhuriyeti tanımlayan kavramlar olamaz. Bunlar, monarşide de cumhuriyette de görülen özellikler olabilmektedir. 
Yani, bir monarşi anti-demokratik olabileceği gibi, demokratik de olabilir. Bu yargının doğruluğu ampirik olarak kanıtlanmıştır. Örneğin Suudi Arabistan, Ürdün gibi birçok devletin anti-demokratik birer monarşi iken Avustralya, Belçika, Birleşik Krallık, Danimarka, gibi devletler cumhuriyet rejimine sahip olmamalarına karşın birer demokratik monarşidirler. Aynı şekilde cumhuriyet rejimi demokratik olabileceği gibi, İran ve Irak örneğinde olduğu şekliyle anti-demokratik de olabilir. (Gözler, 1999: 55).

\section{Milli Mücadele Yıllarında Cumhuriyetçi Düşünce ve Uygulamalar}

Türkiye'de cumhuriyetin dayanağını oluşturan milli hâkimiyet kavramı üzerinde Osmanlı'nın son dönemlerinden itibaren anlam ve algı birliği oluşturulamamıştır. İttihat Terakki Cemiyeti'nin yönetimi ele geçirmesiyle birlikte bu kavram, kutsal bir anlam yüklenerek hükümetlerin her türlü icraatlarını meşrulaştırmak amacıyla kullanılmaya başlanmıştır.

Milli Mücadele dönemine kadar, meşrutiyet yıllarında milli hâkimiyet kavramı, monarşinin karşıtı olarak ülke yönetiminde tek yetkili organın halkın seçtiği temsilcilerinden oluşan parlamenter rejimi, cumhuriyeti ifade etmemekteydi. Milli egemenlik kavramı bu anlamını Milli Mücadele yıllarında kazanmıştır (Tunaya, 2009:178; Turan, 1996: 108-109). Bu dönemde milli egemenlik ilkesine bağlı kalınarak kurulan bölgesel ve ulusal nitelikteki kongre siyasal iktidarları tamamen halkın temsilcilerinden oluşmaktaydı. Batı Anadolu'da, Trakya ve Doğu Anadolu'da oluşturulan bölgesel yönetimler meşruiyetlerini, doğrudan halktan, milletten alıyorlardı. Örneğin, Balıkesir kongreleri, Alaşehir, Nazilli kongreleri ve bunların kurmuş oldukları heyeti merkeziyeler, Erzurum Kongresi tarafından oluşturulan Temsil Heyeti'nin benzerleriydi ve gücünü bölge halkından almaktaydı (Tanör, 2009: 169; Feyzioğlu, 1985: 742744; İlgüner, 1999: 1-258; Konukçu, 2000: 78-182). Kars'ta 1918 yılı sonlarında halk tarafından kurulan bölgesel hükümetin adı Mart 1919'da "Cenûb-i Garbi Kafkas Hükûmet-i Cumhuriyesi" adını almıştı. Batı Anadolu'daki Kongre iktidarlarının faaliyetleri İstanbul Hükümetince cumhuriyetçi hareketler olarak suçlanmıştır (Tanör, 1996: 94; Turan, 1996: 112).

1919 Haziranında yayınlanan Amasya Genelgesi Türkiye'de milli iradenin egemen kılınacağına vurgu yapmakta ve bu yönüyle de kurulacak yönetimin cumhuriyet ilkelerine uygun olacağını ima etmekteydi. Yavuz Abadan'a göre ortaya koyduğu ilkeler sayesinde inkılap idaresinin ilk hukuki ifadesi olarak milli hareketin ve hukuki tanzim faaliyetlerinin başlangıcıdır (Abadan, 1960: 45).

Erzurum Kongresi milli egemenliği esas alan yeni Türk devletinin kuruluşu açısından daha ileri bir adım sayılır. Kongre kuvayı milliyeyi amil ve milli iradeyi hâkim kılmayı ilke olarak kabul etmiştir. Yine Kongre, vatanı ve istiklali merkezi hükümetin koruyamaması durumunda bir geçici hükümetin kurulacağını karar altına almıştır. Aslında sözü edilen milli hükümet Temsil Heyetinin oluşturulmasıyla bu kongre tarafından kurulmuş oluyordu (Atatürk, 1970, C.I: 66; Atay, 2010: 219; Eroğlu, 1982:189)

Mustafa Kemal Paşa daha Erzurum Kongresi günlerinde ileride kuracak olduğu siyasal rejimin cumhuriyet olacağını Mazhar Müfit Bey'e not ettirmiştir (Kansu, 1997: 74).

Eylül 1919 gerçekleştirilen Sivas Kongresi ile ülkede faaliyette bulunan müdafaa-i hukuk cemiyetleri bir merkezde toplanmış ve Temsil Heyeti memleketin mukadderatına el koyan bir hükümet halini almıştı. Bu tarihten sonra Temsil Heyeti ulusal çapta bir cumhuriyet hükümeti 
gibi faaliyet göstermiştir. Mustafa Kemal Paşa'nın liderliğinde gerçekleştirilen kongrelerin almış olduğu kararların tamamında milli iradeyi hâkim kılma ilkesinin kabul edildiği görülmektedir. (Atay, 2010: 228; Aydemir, 2011, C.II: 124). Bu ilke Milli Mücadelenin meşruiyet temelini oluşturduğu gibi kurulan yönetimin demokratik niteliğine de işaret etmektedir.

Sivas Kongresi ile Milli Mücadele hareketi Anadolu'da güç kazanmıştır. Milliyetçiler artık Mustafa Kemal'in dediği gibi İstanbul Hükümeti'ne bağlı değil, İstanbul Anadolu'ya tabi olacaktı. İngiliz Amirali de Robeck, 17 Eylül 1919'da İstanbul'dan Lord Curzon'a gönderdiği raporda Türkiye'deki gelişmelerin cumhuriyete doğru bir yöneliş olduğunu açıklamaktaydı (Şimşir, 1973, C.I: 104; Eroğlu, 2014: 31).

Milli egemenlik temeline dayanan ilk meclis 23 Nisan 1920'te Ankara' da toplanmıştır. Türkiye Büyük Millet Meclisi açıldığı günden itibaren kurulan yeni devletin hükümet şekli demokratik bir cumhuriyet idi. Mustafa Kemal Paşa'nın 24 Nisan'da Meclis tarafından kabul edilen önergesi Hükümetin bu niteliğini belgelemektedir. Önergeye göre Büyük Millet Meclisinin üstünde hiçbir kuvvet olmayacaktı. Meclis, yasama ve yürütme görevlerini elinde bulunduracak, hükümet işlerini görmek için Meclis Başkanı'nın idaresinde bir heyet seçecekti. Önergeye eklenen dipnot ile 'Padişah ve Halife, her türlü zor ve baskıdan kurtulduğu zaman Meclisçe kararlaştırılacak yasal ilke içerisinde yerini alacağı belirtiliyordu (TBMM ZC, Devre I, C.I: 32). Mustafa Kemal Paşa bu kararlara göre kurulan hükümet için “hâkimiyeti milliye esasına müstenit halk hükümetidir. Cumhuriyettir" demektedir (Atatürk, 1970, C.II: 438).

TBMM olağanüstü yetkilere sahip bir meclis idi. Meclisin bu niteliğe sahip olması demek, anayasa ve kanun yapma yetkisini serbestçe kullanması demektir. 24 Nisan kararları adı anayasa olmasa da anayasa prensipleri idi (Eroğlu, 2014: 37-38).

Mustafa Kemal Paşa tarafından Halk Zümresinin programından esinlenerek oluşturulan halkçılık programı bir anayasa tasarısı olarak 13 Eylülde Meclise sunulmuş, 18 Eylülde de Mecliste okunmuştur. Halkçılık programı 20 Ocak 1921 Teşkilat-1 Esasiye Kanunu'nun çerçevesini oluşturmuştur (Özbudun, 2008: 19; Demirel, 2003: 185; Tunçay, 1978: 156). Bu programın 6. maddesi, daha sonra Teşkilat-1 Esasiye'nin ilk maddesini oluşturacaktır ve şöyledir: "Hâkimiyet kayıtsız şartsız milletindir. İdare usulü halkın mukadderatını bizzat idare etmesi esasına dayanır (Karal, 1981: 24; Özbudun, 2008: 76). Bu ilkeler uygulanmak istenen yönetim usulünü ortaya koymaktaydı. Atatürk, 8 Ocak 1921'de yaptı̆̆ bir konuşmada; “Türkiye Büyük Millet Meclisi kuvveî teşriiye ve icraiyeyi nefsinde cemetmiş ve bütün mukadderatı millet ve memlekette fiilen vazülyed bir heyettir. Yani hükümet kendisidir." sözleriyle hem meclisin kuruculuk vasfına göndermede bulunmuş hem de siyasal sistemin halkçı yani demokratik yapısına vurgu yapmıştır (Atatürk, 1997: 147). Teşkilat-1 Esasiyenin ilk üç maddesi de bu konuya yeterince açılılık getirmektedir:

“Madde 1. Hâkimiyet bilâ kaydüşart milletindir. İdare usûlü halkın mukadderatını bizzat ve bilfiil idare etmesi esasına müstenittir.

Madde 2. İcra, kudreti ve teşrii salâhiyeti milletin yegâne ve hakiki temsilcisi olan Büyük Millet Meclisinde tecelli ve temerküz eder.

Madde 3. Türkiye Devleti, Büyük Millet Meclisi tarafından idare olunur ve hükümeti Büyük Millet Meclisi Hükümeti unvanını taşır (Kili-Gözübüyük, 1985: 91; Özbudun, 2008: 81). 
1921 Anayasasının bu ilk üç maddesi siyasal gücün kaynağını, egemenliği kullanacak yegâne kurumu ve yeni devletin yönetim biçimini açıklamaktadır. Bu niteliği sayesinde Ocak 1921 Anayasası, egemenliğin halka verildiği, bütünüyle onun tarafından kullanılmasının kabul edildiği ilk siyasal belgedir (Albayrak, 2010: 63). A. Fuat Başgil'e göre 1921 Anayasası reisicumhursuz bir cumhuriyet kurmuştur (Eroğlu, 2014: 43).

Taha Parla' ya göre 1921 Anayasasının birinci maddesi ile Türkiye'de cumhuriyeti yalnız fiilen değil hukuken de kurmuştur. Parla, Saltanatı kaldıran Meclis kararının “(Türk milleti) Teşkilatı Esasiye Kanununu çıkararak onun birinci maddesi ile hâkimiyeti Padişahtan alıp bizzat millete... vermiştir" derken, halkın egemenliğin tek sahibi olduğu gerçeğini pekiştirdiğini belirtmektedir. Parla'ya göre cumhuriyete giden yolda 29 Ekim 1923 Kanunu önemsiz değil ama esas olarak biçimsel bir aşamaydı (Parla, 1991: 12).

Bülent Tanör, 1921 Anayasası hazırlanış ve kabul özellikleri bakımından Osmanlı-Türk anayasacılığının en demokratik, belki de tek demokratik örneğidir yorumunu yapmaktadır (Tanör, 2012: 250).

1 Kasım 1922 tarihinde Saltanatın kaldırılması cumhuriyet için önemli bir aşamadır. Bu sayede cumhuriyetin önündeki büyük bir engel kaldırılmış oldu. TBMM'nin aldığı bu tarihi kararın gerekçesi milli egemenliğin tecellisini göstermesi bakımından ilgi çekicidir: "... Türk milleti saray ve Babıâli'nin hıyanetini gördüğü zaman Teşkilat-ı Esasiye Kanununu ısdar ederek onun birinci maddesiyle hâkimiyeti padişahlıktan alıp bizzat millete ve ikinci maddesiyle icrai ve teşrii kuvvetleri onun yedi kudretine vermiştir" (TBMM ZC, Devre I, C.24: 313).

$\mathrm{Bu}$ tarihi karar sayesinde 1921 Anayasası ile kurulmuş siyasi rejim geniş anlamıla cumhuriyetten başka bir şey değildi. Fakat cumhuriyet resmen ilan edilmemiş ve devlet başsız bir devlet olarak kurulmuştu (Eroğlu, 2014: 46).

\section{Cumhuriyetin İlanı ve Bu Süreçte Ortaya Çıkan Muhalefet}

1923 'te Cumhuriyet'in ilan edilmesi temel bir rejim değişikliğidir. Milli Mücadele hem millet olma hem de yeni bir siyasi düzene, demokrasiye geçiş mücadelesidir. Türkiye'de demokrasinin ruhunu Milli Mücadelede ve Birinci Büyük Millet Meclisi'nde bulmak mümkündür.

Gerçekte 23 Nisan 1920 de yeni bir Türkiye devleti kurulmuştu. Milli egemenlik ilkesine dayanması ve demokratik yapıya sahip bulunması yönüyle bu devletin adı Cumhuriyet olması gerekiyordu. Ancak o günlerde Cumhuriyet kavramını telaffuz etmek sakıncalı görüldüğünden devlete ismi konmamıştı. Hükümetin adı, Türkiye Büyük Millet Meclisi Hükümeti idi. Meclisin başkanı hükümetin de başkanı idi. Bu durum devlet başkanlığının boş olduğu izlenimini veriyordu (Karal, 1981: 126).

Cumhuriyet, yüz yıllarca saltanatla yönetilmiş ve ardından kısa süre meşrutiyet tecrübesine sahip bir toplumda kolay kabul edilebilecek bir siyasal rejim değildi. Her türlü köklü değişime karşı olan ve din adına hareket ettiklerini iddia eden radikal muhafazakârlar, Halifenin gücünü ne pahasına olursa olsun korumak istiyor, bir kısmı da cumhuriyet ilân edilecekse, Halifenin cumhurbaşkanı olması gerektiğini ileri sürüyorlardı. Bazı yazar ve adınlar da Fransa, ya da Amerika'daki gibi gerçek bir demokratik cumhuriyet kurulmasını uygun buluyorlardı. Bir yandan da cumhuriyetin Mustafa Kemal' in elinde Güney Amerika ve Sovyet Rusya'da olduğu gibi, bir çeşit diktatörlüğe dönüşmesinden çekiniyorlardı. Her ikisi de 
demokrat olan Ali Fuat Paşa ile Rauf Bey bu görüşteydi. Gazi'nin başında bulunduğu inkılapçı çoğunluğun görüşü ise cumhuriyetin süratle ilan edilmesiydi. Rauf Beyin başını çektiği muhalifler Mustafa Kemal'in Meclis'te Cumhuriyeti bir oldubitti ile ilân etmesinden korkuyorlardı.(Kinross, 1966: 446; Eroğlu, 2014: 56)

Gazi, 22 Eylül'de Neue Freie Presse adlı bir Avusturya gazetesine verdiği mülakatta ilk defa cumhuriyet kavramını açıça ortaya atmış bulunuyordu. Bu mülakat 27 Eylül'de Hâkimiyet-i Milliye gazetesinde yayınlanmıştır. Avusturyalı gazetecinin sorusuna Mustafa Kemal Paşa'nın cumhuriyetin ilanı ile ilgili cevabı çok kesindi:

Yeni Türkiye Teşkilât-1 Esasiye Kanununun ilk maddelerini tekrar edeceğim:

"Hâkimiyet bilâ-kayd'ü şart milletindir. İcra kudreti, teşriî salâhiyeti milletin yegâne hakiki mümessili olan mecliste tecelli ve temerküz etmiştir."

Bu iki kelimeyi bir kelimede özetlemek mümkündür. "Cumhuriyet". Yeni Türkiye'nin yenilenme çalışmaları daha son bulmamıştır. Harpten sonra Türk Teşkilât-1 Esasîyesi'nin inkişafı henüz kesin bir şekil almış sayılmaz. Değişiklik ve düzeltme yapmak ve daha mükemmel bir hale getirmek gereklidir, tamamlanmaya çalışılan bu iş henüz bitmemiştir. Kısa bir süre içinde Türkiye'nin bugün fiilen almış bulunduğu şekil kanunen de tespit edilecektir. Yakın bir gelecekte bu konuya ait hükümet teklifleri meclise arz edilecektir. Bu tekliflerin bütün maddeleri Teşkilât-1 Esasiye Kanununun inkişaf ve ikmaline ait bulunacaktır. Bütün Avrupa ve Amerika'daki cumhuriyetler nasıl esas itibariyle yekdiğerinden ayrı değilse aralarındaki fark nasıl yalnız şekle ait bulunuyorsa, Türkiye'nin de bu cumhuriyetlerden farkı sırf bir şekil meselesidir (Vatan, 24.9.1923; Hâkimiyet-i Milliye, 27.1.1923; Atatürk'ün Söylev ve Demeçleri, 1997, C.I-III: 86-87).

Oysa Mustafa Kemal Paşa kısa bir süre önce yabancı bir gazetecinin sorusuna verdiği cevapta Teşkilât-ı Esâsiye Kanunu ile kurulan meclis hükümeti sisteminin milli egemenliği en iyi bir şekilde yansıttığını ve cumhuriyetten daha iyi bir hükümet şekli olduğunu belirtmekteydi İkdam: 11 Mart 1923; Özkaya, 1993: 279). Mustafa Kemal Paşa Kurtuluş Savaşı yıllarında siyasal rejim konusundaki bu görüşünü dile getirip savunmuştur. Meclisteki mebusların birçoğu mevcut hükümet sistemi konusunda aynı düşüncedeydiler (TBMM ZC, Devre I, C.14: 828).

Gazi'nin 1923 Eylülü sonlarında rejimin cumhuriyet olacağ1 şeklindeki sözlerine kimseden olumsuz bir tepki gelmemiştir. Basında "cumhuriyet esaslarının kabulü için mebuslar arasında büyük bir eğilim vardır" şeklinde haberler çıkmıştır(Vatan, 23.9.1923; Yalman, 1997,C. II: 884; Akyol, 2012: 312).

Cumhuriyete doğrudan karşı çıkan pek yoktu. Bazı aydın ve muhalifler rejimin adının da belirleneceği yeni anayasayla ilgili çalışmaların yürütüldüğü günlerde 1921 Teşkilat-1 Esasiye Kanunu'nun getirdiği düzende milli hâkimiyet ilkesinin zayıflatılması endişesini taşıyorlardı. Cumhuriyetin ilanından kısa bir süre önce başlayıp, 29 Ekim sonrası devam eden muhalefetin eleştirilerinin en önemli nedeni, meclisin yetkilerinin bir bölümünün devlet başkanına devredilerek siyasal sistemin otoriterleşmesi tehlikesiydi (Ebuzziyazade, Tevhid-i Efkar, 26.9.1923; 18.10.1923; Hüseyin Cahit, Tanin, 31.10.1923; Yalman, 1997: 903)

5 Ekim günü Gazi'nin başkanlığında toplanan Halk Fırkası büyük divanı yeni Türk devletinin isminin Türkiye Cumhuriyeti olmasına karar vermiştir. Mustafa Kemal Paşa'ya yakın gazeteler, "Yakında cumhuriyet ilân olunacaktır, Yeni cumhuriyetimizin reisi Mustafa Kemal 
Paşa hazretleri olacaklardır" şeklinde açıklamalarda bulunmuşlardır(İstikbal, 27.9.1923; Hâkimiyeti Milliye, 27.9.1923; Eroğlu, 2014: 56).

Enver Ziya Karal'a göre Atatürk, yeni Türkiye devletinde cumhuriyetin ilanını üç nedenle zorunlu görmekte idi. Halife ve saltanat yanlısı olanların devlet başkanlığı makamı için kriz oluşturmalarını önlemek birinci ve en önemli nedendi. İkincisi, yabancı devletlerin Türkiye' de siyasal rejimin istikrara kavuşmamış olduğu yolundaki kuşkularını önlemek, üçüncüsü ise halifelik makamından güç alacak olan eski rejim yanlılarına karşı yapılacak inkılâpları güvence altına almaktı. Atatürk, bu nedenlerle 1923 Eylülünde, cumhuriyetin ilanını zamanının geldiğine karar vermiştir (Karal, 1974: 837).

Ekim ayının sonlarına doğru Gazi'ye cumhuriyetin ilanı için fırsat veren bir takım gelişmeler yaşanmıştır. Konuya netlik kazandırabilmek için bazı önemli olaylar tarih sırasına göre verilecektir.

24 Ekimde Ali Fuat Paşa Meclis İkinci Reisliği'nden istifa etmiştir. Paşa Konya'daki İkinci Ordu Müfettişliği'ne atanmak istemiştir. Ali Fuat Paşa'nın yerine iki gün sonra Halk Fırkası grubu, muhalif Rauf Bey'i seçmiş ve böylece cumhuriyetin ilanıyla sonuçlanan kriz için önemli bir fırsat doğmuştur (Atatürk, 1970, C. II: 794, 797; Cebesoy, 2002, C. II: 30-31; Aydemir, 2011, C. III: 141-142; Akyol, 2012: 313).

Ali Fuat Paşa'nın istifa ettiği gün Rauf Bey saltanatın kaldırılması tarihinin milli bayram olması için kanun teklifi vermiştir. Aynı gün Rauf Bey'in teklifi Meclisçe itirazsız kabul edilmiştir (TBMM ZC, C. 3: 14-16; Öztürk, 1989, C. I: 192). Hâlbuki Rauf Bey k1sa bir süre sonra cumhuriyet karşıtı saltanatçı olmakla suçlanacaktır (Atatürk, 1970, C. II: 684, 793, 824-825).

24 Ekimde konumuz açısından önemli bir olay daha gerçekleşmiştir. Başvekil Fethi Bey kendisini tamamen Başbakanlık işlerine vermek için Dâhiliye Vekilliğini bırakmıştır (Aydemir, 2011, C. III: 141).Dâhiliye Vekilliği'nin boşalması, cumhuriyeti doğuracak hükümet krizi sebeplerinden birini oluşturacaktır.

25 Ekim'de Halk Fırkası Meclis Grubu'nda yapılan seçimleri Gazi'nin desteklediği adaylar kaybetmiştir. Mecliste muhalefetin güçlendiği anlamına gelen bu olay Gazi'yi tedirgin etmiştir. Gazi'nin partisinin mebusları Meclis ikinci başkanlığı için muhalif Rauf Bey'i, İçişleri Bakanlığı için yine muhalif Erzincan Mebusu Sabit Bey'i seçmiştir. Hem de "ekseriyet-i azime" yani büyük çoğunlukla (Atatürk, 1970, C. II: 797; Aydemir, 2011, C. III: 141-142; Akyol, 2012: 314).

Gazi bu durumdan rahatsız olmuştur. Nutuk'ta "seçimlerde fırkamız namına mebuslukları temin edilmiş" olan mebusların şimdi Gazi'nin adaylarına oy vermemelerini, “bizimle görüş ve faaliyetlerde uzlaşma ve beraberlik aramaya lüzum görmeksizin bağımsız ve gizli çalışan bir hizip" diye eleştirir. "Bu hizip saf ve suret-i haktan görünerek bütün fırka mensuplarını kendi görüşleri lehine çekmeye muvaffak olmaya başlamıştı" (Atatürk, 1970, C. II: 798-799; Akyol, 2012: 315).

Rauf ve Sabit beylerin seçilmelerini eleştiren Gazi, özellikle Rauf Bey'in seçilmesine kızmıştır. Nutuk'ta bunu açıkça belirtir; "hafi bir hizb-i kalil” (gizli bir küçük hizip) tarafından meclis "iğfal" edilmiş, aldatılmıştır demekte veMeclisi iğfale çalışan bu hizip için "muhteris" nitelemesinde bulunmaktadır (Atatürk, 1970, C. II: 798-799; Kinross, 1966: 446). Şevket Süreyya Aydemir, Atatürk'ün kendisine muhalefet edenleri eleştirmek amaciyla kullandığ 1 muhteris sıfatını şu şekilde yorumlamaktadır: 
"Siyasî bir belge olan Nutuk'ta, o günlerle ilgili bu beyanları, o günlerdeki siyasî ruh halinin ifadesi olarak almakla yetinmelidir. Çünkü o günkü şartlar içinde ihtiras, Meclisin havasına elbette ki hâkim olacaktı. Öyle ki, o koşullar içinde ve doğal olarak, Meclisin sıralarında yer alan herkes muhteristi. Çünkü yeni bir devlet kurulmuştu. Şimdi yeni düzende ve yeni hükümet yapısında yerlerini almak isteyeceklerdi. Meclisin içinde arka planlara itilmek ve birer gölge haline gelmek korkusu duyabilirlerdi. Bu da normal bir haldi" (Aydemir, 2011, C. III: 143).

Taha Akyol'un deyimiyle Gazi, kurmay dehasıyla öyle bir siyasi plan yapmıştır ki, hem meclisteki bu muhalefeti etkisizleştirmiş, hem de cumhuriyetin ilanını sağlamıştır.

Uygulamadaki vekillerin (bakanların) seçimi yöntemi hükümetin kurulmasını güçleştiriyordu. Başbakanın ve bakanların teker teker mecliste seçilmesi bakanlar arasında uyumsuzluğa ve istikrarsızlığa yol açıyordu. Milli Mücadele döneminde de bu türden sorunlarla karşılaşılmıştır (TBMM ZC, Devre I, C. 5: 292-297; Akyol, 2012: 315).

Gazi'ye planladığı hükümet krizini devreye koymak için fırsat doğmuştur. Rauf ve Sabit Beyler Halk Fırkası Grubunda aday seçilir seçilmez Gazi derhal, 25 Ekim akşamı Fethi Bey başkanlığındaki Bakanlar Kurulu'nu Çankaya'da toplamıştır. Hükümetin ahenkli ve istikrarlı olamayışının sebebinin Başvekil ve vekilleri teker teker Meclisin seçmesi, yani meclis hükümeti sistemi olduğunu anlatmıştır. Çözüm kabine sistemine geçmektir, bunun da yolu cumhuriyet rejimi, yani başvekilin cumhurbaşkanınca atanmasıdır (Atatürk, 1970, C. II: 798; Atay, 2010: 437). Milli Mücadele yıllarında Mustafa Kemal Paşa, Meclisteki II. Grup üyelerinin daha güçlü ve uyumlu hükümetler kurulabilmesi için parlamenter hükümet (kabine) sistemi önerilerine, uyumlu ve istikrarlı hükümet o kadar da gerekli değil diyerek karşı çıkmıştı (TBMM ZC, Devre I, C. 14: 437).

26 Ekim Cuma günü Gazi, Başvekil Fethi Beyle bütün vekillerin istifa etmelerini istemiş, onlar da istifa dilekçelerini Gazi'ye vermişlerdir.

Gazi, Fethi Bey'in ve Fevzi Paşa dışındaki bütün bakanların istifasını aldıktan sonra, onlara mecliste kurulmak istenecek yeni bir hükümette yer almamalarını da tembih etmiştir (Atatürk, 1970, C. II: 798-799).

O zaman Genelkurmay Başkam Fevzi Paşa bakan statüsündedir ve istifadan hariç tutulmasının sebebi bellidir. Karabekir ve Ali Fuat gibi kumandanların komplo hazırlamasından şüphelendiği bir dönemde Gazi "ordu ve kumandasını tesadüfî bir zata tevdi" etmeyi caiz görmemiştir (Atatürk, 1970, C. II: 799, 854; Akyol, 2012: 316).

Kabine istifasını, 27 Ekim Cumartesi günü, Gazi'nin başkanlığında toplanan grup umumî heyetine bildirmiş, aynı gün akşamüzeri de istifa, Meclis umumî heyetinde okunmuştur. Hemen geniş bir kulis faaliyeti başlamış, mebuslar, çeşitli kabine listeleri düzenlemeye başlamışlardır. İşte muhalefetin teşkilâtsızlığı da bu arada kendini göstermiştir. Mecliste karşı taraf olarak kendini hissettiren elemanlar, teşkilâtlı bir mukavemet için hazır değildiler. Goloğlu'nun anlatımıyla olağanüstü zeka, görüş ve sezişiyle Gazi, bu kadar heveslinin bulunduğu yerde meclis çoğunluğunun güvenini sağlayabilecek bir Bakanlar Kurulu listesinin yapılamayacağını biliyordu. Gazi istemediği için de böyle bir liste oluşturulamamıştır. (Aydemir, 2011, C. III: 142; Eroğlu, 2014: 61; Golağlu, 2011: 323).

28 Ekim Pazar günü Halk Fırkası'nın yönetim kurulu yeni hükümet kurma çalışmaları için toplanmıştır. Ancak bir hükümet listesi yapamamışlar ve hükümet kurulamamıştır. Gazi, 
siyasal sistemin adını koymak için akşam yakın arkadaşlarıyla Çankaya'da toplanmıştır. Yemek esnasında yarın cumhuriyeti ilan edeceklerini söylemiştir (Atatürk, 1970, C. II: 802-803; Atay, 2010: 439; Albayrak, 2010: 83).

Bu yedi kişilik toplantıda bulunan Kâzım (Özalp) Paşa'nın anlattığına göre, Gazi teker teker herkesin nasıl davranacağının talimatını vermiştir. Onların görevi hükümetin kurulmasını engelleyecek konuşmalar yapmaktı. Hükümetin kurulamayacağ Kemalettin Sami Paşa vereceği önergeyle Gazi'nin davet edilmesini ve krizin çözümünün ona bırakılmasını teklif edecekti. Gazi o gece yalnız İsmet Paşa'yı alıkoydu ve önceden hazırladığ 1 20 Ocak 1921 tarihli Teşkilatı Esasiye Kanununun bazı maddelerini tadil eden tasarıya son şeklini verdi (Aydemir, 2011, C. III: 147)

Aslında Anayasa değişikliğini öngören taslak metin yaklaşık üç ay önce Mustafa Kemal Paşa tarafından hazırlanmış ve Adliye Vekili Seyit Bey'e incelettirilmiştir. Bu çalışmalar henüz o tarihlerde gizli tutulmakta, cumhuriyet hala milli bir sir olarak saklanmaktaydı (Soyak, 1973: C. I: 181-182)

Halk Fırkası Meclis Grubu, cumhuriyetin ilan edileceğinden habersiz hükümet krizini çözmek için, grup idare heyeti başkanı Fethi Bey'in (Okyar) başkanlığında 29 Ekim sabahı toplanmıştır. Fakat Gazi istemediği için bakanlar seçilemiyor ve hükümet yine kurulamıyor. Plan gereğince, Kemalettin Sami Paşa, Gazi'nin davet edilerek hükümet krizinin çözümünü ona bırakmayı önermiş ve kabul edilmiştir. Gazi kürsüye gelip, kendisine bir saat kadar izin verilmesini daha sonra çözüm şeklini arz edeceğini bildirmiştir (Atatürk, 1970, C. II: 804-808; Atay, 2010: 439-440).

Gazi Meclisteki odasına çekilerek yakın arkadaşlarıyla son görüşmelerde bulunmuş, Fırka grup toplantısına gelerek kısa bir konuşma yapmış, "mühim ve müstacel [ivedi] olan maddelerin hemen müzakere edilmesini teklif ederim" diyerek İsmet Paşa ile son şeklini verdikleri Teşkilat-ı Esasiye Kanunu değişikliği taslağını okuması için katiplerden birine verip kürsüden inmiştir. Gazi'nin önergesine göre hükümet krizini çözmenin formülü, başvekili cumhurbaşkanının ataması, bakanları başbakanın seçmesidir. Cumhuriyetin o gün ilan edileceğini mebuslar bu şekilde öğrenmişlerdir (Atatürk, 1970, C.II: 809; Akyol, 2012: 319).

Mecliste okunan teklif, anayasanın 1,2,4,10,11 ve 12. Maddelerinin değiştirilmesini ve hükümet şeklini ve bununla ilgili değişiklikleri öngörüyordu.

Önergede iki madde eleştirilerin odağı olması açısından öne çıkmaktaydı: Cumhurbaşkanı istediği zaman meclise başkanlık edebilecekti, Başvekili cumhurbaşkanı seçecekti (Eroğlu, 2014: 63; Akyol, 2012: 319).

Gazinin teklifinden sonra müzakereler hemen başlamıştır. Sabit (Erzincan), Abidin (Saruhan)Beyler gibi bazı milletvekilleri Teşkilat-ı Esasiye Kanunu'nun değiştirilmesiyle bunalımı çözmenin mümkün olmadığını, önce Heyet-i Vekile reisinin seçilmesini, anayasa değişikliğinin sonra görüşülmesinin daha doğru olacağını savunuyorlardı (Atatürk, 1970, C.II: 809-811).

Fırka (Parti) toplantısında söz alan İsmet Paşa, Fırka reisinin teklifinin kabul edilmesi gerektiğini ifade ederek konuşmasını şöyle sürdürmüştür: “Cihan bizim bir şekli hükümet görüştügüumüzü biliyor. Bunu bir neticeye raptedip ifade etmemek, zaif ve teşettütü (aykırılık) idameden başka bir şey değildir. Avrupa diplomatları bu hususta beni ikaz ettiler. Millet 
hâkimiyetine, mukadderatına, bilfiil vazulyettir. $O$ halde bunun ifadei hukukiyesini söylemekten neden çekiniyorsunuz? ..."

İsmet Paşa'dan sonra söz alan Meclisin en yaşlı üyesi Abdurrahman Şeref Bey anayasa değişikliğinin ne anlama geldiğini açıklayan şu kısa konuşmayı yapmıştır: "Eşkâli hükümetin taâdadına lüzum yok. Hâkimiyet bilâkaydüşart milletindir; dedikten sonra kime sorarsanız sorunuz, bu, cumhuriyettir. Doğan çocuğun adıdır. Ama bu ad, bazılarına hoş gelmezmiş, varsin gelmesin" (Atatürk, 1970, C.II: 811-812; Goloğlu, 2011: 326).

Gazi'nin cumhuriyet tasarısı Halk Fırkası grup toplantısında kabul edilmiştir. Ardından tasarı cumhuriyetçi Yunus Nadi'nin başkanı olduğu Teşkilat-1 Esasiye Encümenine sevk edilmiştir. Encümende tasarıya karşı herhangi bir engelleme olmamıştır. Teşkilat-1 Esasiye Encümeni hazır bulunan 11 üyesiyle önergeyi görüşmüştür. Bu üyelerden dördü reisicumhurun aynı zamanda meclise başkanlık edebilmesini uygun bulmayarak "muhalefet şerhi" yani karşı oy yazısı yazmışlardır (Aydemir, 2011, C. III: 148; Akyol, 2012: 321-322).

Meclise sevk edilen cumhuriyet tasarısı müstacelen ve derakap (ivedilikle) görüşülme karanın alınmasının ardından, genel kurulda hazır bulunan 158 üyenin oybirliğiyle, sürekli alkışlarla kabul edilmiştir (TBMM ZC, Devre I, C. 3: 89-98; Tanin, 30.10.1923).

Türkiye'de Cumhuriyetin ilanını ve meclis hükümetinden parlamenter rejime geçilmesini sağlayan Anayasa değişikliği maddelerinin dördü şöyledir:

Madde 1. - Hâkimiyet; bilâkaydüşart milletindir. İdare usulü halkın mukadderatını bizzat ve bilfiil idare etmesi esasına müstenittir. Türkiye Devletinin şekli Hükümeti, Cumhuriyettir.

Madde 10. - Türkiye Reisicumhuru, Türkiye Büyük Millet Meclisi Heyeti Umumiyesi tarafından ve kendi âzası meyanından bir intihap devresi içim intihap olunur. Vazifei Riyaset yeni Reisicumhurum intihabına kadar devam eder. Tekrar intihab olunmak caizdir.

Madde 11. - Türkiye Reisicumhuru Devletin Reisidir. Bu sıfatla lüzum gördükçe Meclise ve Heyeti Vekiliye riyaset eder.

Madde 12. - Başvekil Reisicumhur tarafındanve Meclis âzası meyanından intibabolunur. Diğer vekiller Başvekil tarafından yine Meclis âzası arasımdan intihab olunduktan sonra heyeti umumiyesi Reisicumhur taraflımdan Meclisin tasvibine arz olunur. Meclis hali içtimada değilse keyfiyeti tasvip Meclisin içtimaına talik olunur (TBMM ZC Devre I, C. 3: 9098).

Cumhuriyeti ilan eden yasanın kabulünden hemen sonra cumhurbaşkanlığı seçimine geçilmiş ve Gazi Mustafa Kemal Paşa oybirliği ile cumhurbaşkanı seçilmiştir (Atatürk, 1970, C.II: 813; Aydemir, 2011, C.III: 151)

Cumhuriyet tasarısı, genel itibariyle normal bir parlamenter cumhuriyet anayasasının maddeleri niteliğindedir. Ancak, cumhurbaşkanına verilen yetkilerden bazıları normalin ötesindedir. Cumhurbaşkanı gerek gördüğünde sadece bakanlar kuruluna değil, parlamenter rejimlerde asla düşünülemeyecek şekilde Meclise de başkanlık edecektir.

‡Atatürk Nutuk'ta cumhurbaşkanlığı seçimine 158 mebusun katıldığını belirtirken, Aydemir bu sayının 159 olduğunu, bir çekimser oy bulunduğunu, bu oyun da Mustafa Kemal Paşa'ya ait olduğunu kaydetmektedir. Kinross ise yanlışlıkla, cumhurbaşkanlığı seçiminde 58 kişinin oybirliğinden 100 kişinin de çekimser kaldığından bahsetmektedir (Aydemir, 2010, C.III: 151; Kinross, 1966: 447). 
12. maddeyle hükümetin kuruluşunda cumhurbaşkanı daha etkili, hatta asıl yetkili hale gelmiştir. Meclis hükümeti sisteminde Birinci Meclis Gazi'ye başbakan ve bakan atama yetkisi vermemişti. Bu yetkiyi Gazi, cumhuriyetin ilanıyla almıştır.

Cumhurbaşkanına verilen üçüncü istisnai yetki, parti liderliğini devam ettirmesine imkân tanınmasıdır. Normal parlamenter cumhuriyetlerde böylesi bir durum söz konusu olamaz. 1982 Anayasası'nın 101. Maddesinde de cumhurbaşkanı partisizdir. Gazi hem reisicumhur hem de Halk Fırkası'nın başkanıdır. Bülent Tanör'ün ifadesiyle parlamenter sisteme göre bu aykırılık yeni bir geçiş dönemi içinde bulunulmasıyla ve Gazi'nin olağan dışı konumuyla açılanabilir (Resmi Gazete, 9.11.1982, Sayı: 17863; Akyol, 2012: 324; Tanör, 2012: 284; Gözler, 2001: 67).

Bu anayasal değişiklikle Cumhuriyet, Mustafa Kemal Paşa'nın elinde gerçekleşmekte olan yetki yoğunlaşmasını en üstü düzeye çıkaracak şekilde düzenlenmiştir. Andrew Mango'nun belirttiği gibi, Gazi'nin rakibi yoktu, onu ilgilendiren tek nokta, cumhurbaşkanının sahip olacağ1 güç ve ülkeyi yönetme yeteneğiydi(Mango, 2006: 456; Akyol, 2012: 324). Şevket Süreyya Aydemir, Gazi'nin bu kanun değişikliği ile elde ettiği gücü kendine özgü anlatımıla şöyle belirtmektedir: "Kendisini kim bilir nice yılların mihnetleri içinde, düşünülen veya düşünülemeyip de, hayal meyal sezinlenen bir yerlere, ülke içinde üstün ve tek adam'ın temsil edebileceği çağdaş bir iktidara ulaştırmak üzere olan yol, artık açılmıştır. Yolun sonuna gelinmiştir" (Aydemir, 2011, C.III: 149).

Lord Kinross da bu konuda şunları kaydetmektedir: Mustafa Kemal gerektiğinde üstün taktik ve mecbur kaldığında üstü kapalı tehdidi bir arada ustalıkla kullanarak iktidarın en yüksek noktasına ulaşmıştı. Kendinde Devlet Başkanlığı, Hükümetin ve Meclisin gerçek başkanlığı, tek parti başkanlığı olmak üzere üç başkanlığı birden toplamıştı. Selanik'ten beri kendisine hayran olan arkadaşı Tevfik Rüştü onu bir gün Hıristiyanların üçlemesiyle kıyaslamıştı: Baba, Oğul ve Kutsal Ruh.” Gazi gözlerinde bir pırıltıyla (bu benzetmeyi) onayladı: “Öyledir ama kimse duymasın!(Kinross, 1966: 448).

Cumhuriyet'i ilan eden ve Türkiye'yi kabine sistemine geçiren kanun teklifi parti grubunda dört saat, komisyonda bir saat, mecliste de bir buçuk saat görüşülmüştür. Bu acele yüzünden, 15 üyeli Anayasa Komisyonu 11 üyeyle toplanmış, 250 (Tanin Gazetesine göre 286) civarında mebus bulunabilecekken 158 mebus tarafından kabul edilmiştir. Oysa 1921'de kabul edilen Anayasa iki ay içinde tam dokuz birleşim gününde müzakerelerle olgunlaştırılarak kabul edilmişti (Tanin: 31 Ekim 1923; Akyol, 2012: 334).

Cumhuriyetin ilanında acele eden Gazi'nin, olayların akışı incelendiğinde neden böyle davrandığı, amacının ne olduğu anlaşılmaktadır. Gazinin ulaşmak istediği amaç; kendi hazırladığı metinde cumhurbaşkanına verilen sıradışı yetkilerin mecliste tartışılıp aşındırılmasına fırsat vermeden süratle yasalaşmasını sağlamak ve basında yapılan yetki tartışmalarının mecliste yapılmasına meydan vermemekti. Bu hedefle bağlantılı olarak Gazi yasa teklifini, muhalif veya muhalif olabilecek mebusların ve özellikle Rauf Bey, Karabekir, Cebesoy, Adnan Bey gibi etkili isimlerin Ankara dışında bulunduğu 29 Ekim gününde süratle meclisten geçirmek istemişti. Böylece reisicumhurun Tek Parti'nin lideri olabileceği bir düzenleme gerçekleştirilmiştir (Akyol, 2012: 334; Kinross, 1966: 448).

Rauf Bey, Ali Fuat Cebesoy ve Refet Paşa Türkiye'de batılı anlamda demokratik bir siyasal sistemin gelişebilmesi için Mustafa Kemal Paşa'nın bir siyasi partinin başında bulunmasını istemiyorlardı. Zaferin kazanılmasından sonra Gazi'nin bir devlet başkanı olarak siyaset üstü 
kalıp politik anlaşmazlıklarda arabulucu rolünü üstlenmesini istiyorlardı (Karabekir, 1991: 109,118; Cebesoy, 2002: 5; Kinross, 1966: 359-360; Yalman, 1997: 821).

Gazeteci Hüseyin Cahit 2 Kasım 1923 günlü Tanin'de meclisteki görüşmelerin “amiyane tabirle sıkboğaz edildiğini, anayasa değişikliğinin geniş müzakerelerle yapılacağı söylendiği halde "birkaç saat içinde anayasa değişikliğinin yapılıverdiğini" yazıyordu. Hüseyin Cahit'e göre bu acelenin iki amacı vardı. Bunlar Cumhurreisinin aynı zamanda "firka reisi" olabilmesini ve istediğinde meclise başkanlık edebilmesini sağlamaktı (Halkçı Gazetesi, 24.5.1955'den aktaran Akyol, 2012: 334.).Hüseyin Cahit 9 Ekim 1923'te “Mühim Bir Münakaşa" adlı köşe yazısında cumhurreisinin meclis başkanlığından ve parti genel başkanlığından çekilmesi gerektiğini savunmuştu (Tanin, 9.10.1923). Ülke yönetiminin tek adamlığa doğru gittiği endişesini taşıyan Hüseyin Cahit daha bir yıl önce 19 Ekim 1922 tarihli Tanin'de Gazi Paşa'yı kastederek “bir tek adamın dehasına bir millet meclisinin kurulları elbette tercih edilir" diye yazmıştı (Akyol, 2012: 334; Aybars, 1995: 238).

Muhafazakâr Tevhid-i Efkâr gazetesinin başyazarı Ebuzziyazade Velid'in bile savunduğu devlet şekli saltanat değildi. Velid Bey, saltanatın ilgasıyla milli hâkimiyet ilkesinin kesinleştiğini, bunu sağlayan "meclis hükümeti" sisteminin devam etmesini istemekteydi. Önemli olan milli hâkimiyet ilkesinin korunması, cumhuriyet adı altında şahıs hâkimiyetine gidilmemesi idi (Tevhid-i Efkar, 26.9.1923; 18.10.1923). Ancak Ebuzziyazade Velid'in siyasal sistem olarak cumhuriyeti beğenmediği yazılarından açıkça anlaşılmaktadır. Velid Bey, Fransa anayasasının kurduğu cumhuriyet sisteminin meşrutiyetten farksız olduğunu savunmaktaydı (Tevhid-i Efkar, 26.9.1923).

Saltanat kaldırılalı bir yıl olmuştur. Artık o günlerde cumhuriyete karşı saltanatçı bir akım yoktu. Sadece cumhuriyetin o zaman demokrasi anlamında kullanılan milli hâkimiyet ilkesine uygunluğu ve cumhurbaşkanının yetkileri tartışılmaktaydı. Muhalefetin karşı olduğu şey cumhuriyet değil, otoriterleşme idi (Çankaya, 2010: 420, 443, 466; Yalman, 1997: 821;Akyol, 2012: 336).

Atatürk'ün en yakınındaki yazarlardan Falih Rıfkı Çankaya adlı kitabında Karabekir-Rauf Beylerin başını çektiği muhalefet hareketini şöyle anlatmaktadır:

“Aralarında siyasi şöhretler, yarı veya tam aydınlar, şöyle böyle Türkçüler, fakat bilhassa Osmanlılar vardır. Devrimci değildirler. Gerici de değildirler. Bunlar kayıtsız şartsız milli hâkimiyet prensibini tutacaklardır. Mustafa Kemal'in diktatör olmaması için dostça, muhalifçe uğraşacaklardır. Biraz sonra ilk gerçek demokrasi savaşını bunlar verecekler, Terakkiperver Cumhuriyet Fırkasını kuracaklardır. Kendileriyle Mustafa Kemal arasında ayırıcı çarpışma, cumhuriyetin ilan edildiği zaman başlayacaktı"(Çankaya, 2010: 420).

Rauf Bey Cumhuriyetin ilan tarzına ve niteliğine tepkisini İstanbul'da 1 Kasım 1923 günlü Vatan gazetesinde yayınlanan mülakatıyla ortaya koymuştur.

Rauf Bey demokratik cumhuriyeti, “Kuvvetini yalnız ve yalnız milletin muvafakatinden almak...Başka hiçbir tesirin veya kuvvetin karşısında eğilmemek ve halkın ezici çoğunluğunun arzularına uygun olmak" diye tarif ediyordu. Rauf Bey Milli Mücadele'nin en müşkül zamanlarda halk ile temas ederek kazanıldığını anlatıyor ve millet rüştünü ispat etmiştir, yeryüzündeki her millet gibi mukadderatını idareye yeterliliği vardır diyordu. Rauf Bey, gazetecinin cumhuriyet konusunda sorduğu soruya cevap verirken, cumhuriyet kavramına takılmanın doğru olmadığını, en iyi hükümet şeklinin milletimizin refah ve istiklalini, vatanın bütünlüğünü sağlayan şekil olduğunu söylüyordu. Rauf Bey devamla, 
milletin hakiki ihtiyacın doğurduğu bir hükümet şeklini kendine has aklıselimle gerçekleştirdiğini, bunun da en doğru hükümet şekli olan meclis hükümeti sistemi olduğunu belirtiyordu. En iyi hükümet şeklini anlatırken "kuvvetini yalnız ve yalnız milletin muvafakatinden almak... başka hiçbir tesirin ve kuvvetin karşısında eğilmemek ve halkın ezici çoğunluğunun arzularına uygun olmak" gibi demokrasinin temel ilkelerini sıralarken bu sözlerine netlik kazandırmak için şunları söylüyordu: "Aksi takdirde isim değiştirmekle üst tabakada şekil değişmesiyle hakiki ihtiyaçların temin edilmiş olacağını zannetmek özellikle yakın bir geçmişte gördügüumüz acı tecrübelerden sonra büyük hata olur" (Tevhidi Efkar, 1.11.1923; Atatürk, 1970, C.II: 821-823). Taha Akyol, Rauf Bey'in bu sözleriyle İttihat ve Terakki diktatörlüğünü ima ettiğini kaydetmektedir (Akyol, 2012: 345).

Sözü edilen mülakatta Rauf Bey, cumhuriyetin bir günde ilan edilmesinin, bir sorumsuzluk örneği olduğu gibi ağır sayılabilecek ifadeler kullanmıştı.

Rauf Beyin basına verdiği demeç, Ankara' da büyük tepki çekti. Kinross'a göre Mustafa Kemal Paşa, Rauf Bey'le arkadaşlarının bir muhalefet kurmak istediklerini sanarak, onu gözden düşürmeyi ve gericilikle suçlamayı denedi. Rauf Bey, Halifeye bir nezaket ziyaretinde bulunmuştu; bundan, Hilâfetin siyasi bir rol oynaması yolunda birtakım tertiplere giriştiği sonucunu çıkarmak pek zor değildi. Kâzım Karabekir, Rauf Bey'le arkadaşlarına arka çıkıyor ve siyasal sistem konusundaki görüşlerini şöyle dile getiriyordu: “Ben Cumhuriyetten yana, fakat kişisel yönetime karşıyım”. Böylece, Milli Mücadelenin önder kadrosundan dördü şimdi, Mustafa Kemal Paşa'ya karşı açıkça cephe almış oluyorlardı (Kinross, 1966: 449).

Rauf Bey Halk Fırkası grubunda, basına vermiş olduğu demeç üzerine açılamada bulunmaya çağrıldı. Fırka toplantısında Rauf Bey ağır eleştirilere maruz kaldı. Bu demecin, Cumhuriyeti güçten düşürmek amacıyla verildiği ve kendisinin muhalif bir parti kurmak yolundaki niyetini ortaya çıkardığı ileri sürüldü. Toplantıya başkanlık eden İsmet Paşa' ya göre Rauf Bey, sözleriyle, ülkenin anarşiye sürüklenmesine yol açıyordu (Vatan, 28.11.1923; Kinross, 1966: $450)$.

Rauf Bey Parti grubundaki sert eleştiri ve çoğu asılsız olan suçlamalar karşısında üzgündü. İkilik iddiasında bulunmadığını, kendisi hata etmişse, hükümetin de hataları olduğunu, İstanbul'da her mebusa davetname gönderildiği halde kendisine gönderilmediğini, inancını ve görüşlerini söylemek namuskârlık olduğunu, kendisini, söylediklerini yalanlamaya mecbur etmek, memleketin hayrına olmadığını etraflıca anlatarak sözlerini, "Hata etmedim, ben, kesin olarak bu kanıdayım," diye bağırarak sürdürdü ve devam etti:

"Mutlak, muhalif parti yapmamı istiyorlar. Yapmayacağım. Hüküm sizindir. Karar sizindir. Vicdan benimdir. Beni fırkadan ihraç ederseniz yapacağım şey mezuniyet alıp gitmektir. Ben buradan çıkıp gidiyorum... Kararınızı serbest olarak veriniz. Cenab-1 Hak, milletimize saadet versin. Şahıslar payidar (devamlı) değildir. Fikirler her zaman payidardır" (Vatan, 28.11.1923; Cebesoy, 2002, C.II: 52; Aydemir, 2011, C.III: 158).

Rauf Bey hatıratında bu sorulara kısaca şu şekilde cevap verdiğini belirtmektedir: "Bu şekilde konuşanların benden istedikleri, kayıtsız şartsız milli hâkimiyeti sağlamayan herhangi bir idareyi, cumhuriyet olarak kabul etmekliğim idi. Gerçekten cumhuriyetçi olan aklı başında hiç kimse, bunu kabul edemezdi. Verdiğim cevapta, bu noktayı aydınlatarak cumhuriyeti, ancak milli hâkimiyeti tam manasıyla sağlaması şartıyla kabul ettiğimi ve zaten cumhuriyetin de başka manası olmadığını, yoksa Güney Amerika memleketlerinin bazılarında olduğu gibi 
milli hâkimiyeti hiçe sayarak cumhuriyet adı ile hüküm sürülmesinin cumhuriyet sayılamayacağını anlattım" (Orbay, 2003: 567-568; Ekincikli, 2012: 114-155).

Rauf Bey'in açıklamalarına, Mustafa Kemal Paşa, 1927'de Nutkta: “Çünkü söz konusu olan, Millet Meclisi'nce kanunla kabul ve ilan edilen cumhuriyettir. Maksadınız, dolaylı olarak bu ilan olunandan daha uygun bir rejimin bulunduğunu anlatmak ve buna işaret etmek ise, onu da söyleyiniz! O tercih ettiğiniz rejim ne olabilir?" sözleriyle cumhuriyet karşıtlığı anlamı yüklemiştir (Atatürk, 1970, C.II: 824-825; Ekincikli, 2012: 155).

Cumhuriyetin ilanı sonrası Gazi ile eski silah arkadaşlarının arasındaki görüş ayrılıkları daha bir netlik kazanacaktı. Gazi, topyekûn bir inkılâba hazırlanıyordu. Rauf Bey ile arkadaşları, bu dönemde, toplumun ağır ağır gelişmesini daha uygun görüyorlardı. Aceleye, sert ve köklü değişimlere gerek yoktu (Kinross, 1966: 459; Tanör, 2009: 200).

Gazi'nin kafası daha pratik bir yolda çalışıyordu. Ülkesini, Batı ile bir düzeye getirmek için demokrasi (cumhuriyet) kurmuştu; bunun zamanla demokrasi doğrultusunda yürüyeceğine inanıyordu. Batılı meclisinden vazgeçecek değildi. Ancak bu Meclise, aradaki şu dönemde, öyle bir başkan gerekiyordu ki, biraz otoritesini kullansın.

Gazi, dostlarına ve düşmanlarına karşı bir iktidar savaşına girişecekti. Bu savaş, noktası noktasına yorumlanan bir liberal demokrasi ile tek parti hükümetine ve hatta kişisel yönetime bağlı bir demokrasi (cumhuriyet) arasında olacaktı (Kinross, 1966: 460; Çankaya, 2010: 420; Akyol, 2012: 336).

10 Kasım 1923'te İstanbul'a ulaşan Kazım Karabekir'i karşılayan Rauf, Refet ve bir grup gazeteci, Ankara'dan gelen haberden bahsederek Mustafa Kemal'in kendine yeni bir maiyet edindiğini ve tam anlamıyla otoritesini kurma yolunda ilerlediğini gösteriyor, dediler. Artık Mustafa Kemal'in eski dostları onun gücünü ortadan kaldırmak için İstanbul'daki en etkili gazetelerin desteğini almışlardı. Mustafa Kemal'in meclisteki taraftarları da 8 Aralık'ta milletvekillerinden oluşan bir İstiklal Mahkemesi kurarak, özellikle basının içindeki bozguncuları temizlemek üzere İstanbul'a göndermişler ve böylece oluşmaya başlayan muhalefet cephesine tepkilerini göstermişlerdir (Mango, 2006: 461; Ekincikli, 2012: 155)

Gazi'nin milli hâkimiyet ilkesinden saptığı iddia edilemez. Ancak, buna verdiği anlam günümüz anlayışına göre demokratik değil, otoriter-devrimci idi. Atatürk'ün egemenlik anlayışını Bülent Tanör şu şekilde açıklamaktadır: Mustafa Kemal liberal demokrasiyi değil, devrim yoluyla demokrasiye ulaşmayı hedefliyordu... Demokratik bir hedefe demokratik olmayan yöntemlerle de ulaşmaya kararlıydı... Radikaller devrimci cumhuriyeti, muhafazakârlarsa mevcut yasallığı ve demokrasiyi savunuyorlardı. Rauf Bey milli iradeyi egemen kılacak demokrasiye doğru gidilmesi gerektiğini düşünüyordu (Tanör, 2009: 200). Tanör'ün de belirttiği gibi çatışma liberal cumhuriyetle devrimci cumhuriyeti savunanlar arasindaydı.

Bu konuda Şevket Süreyya Aydemir'in analizi aydınlatıcıdır: “İnkılâp tek otorite, tek irade istiyordu. Gazi bunun peşindeydi. Halk Fırkası bu tek iradenin icracısı olan birleşik bir kadro olmalıydı... Karşı taraf ise demokrasinin bir karşılıklı denetim istediğine inanıyor, bir diktatörlüğe gidişten korkuyordu. Onlar da haklıydılar. Zaten Gazi'nin Meclis açılırken ilan ettiği iki hedeften biri demokrasinin geliştirilmesi, demokrasi organlarının kuruluşu idi" (Aydemir, 2011: 159). 
Türkiye'de kurulan tek-parti rejiminin konsolidasyonu (tahkim) sürecini anlatan Ergun Özbudun somut olaylardan hareketle şu açıklamayı yapmaktadır: I. Mecliste II. Grup, hükümet karşısında aktif bir muhalefet partisi gibi çalışarak yönetimin demokrasi çizgisinde yürümesini sağlamıştır. Kemalistlerin kontrolünde yapılan 1923 seçimlerinde II. Grup'tan hiçbir üyenin seçilememesi, birinci dönemdeki çoğulculuğun tasfiyesi yönünde atılmış önemli bir adımdır. Ancak ikinci dönemde de Meclis içinde kısa zamanda bir ayrışma ortaya çıkmıştır. Milli Mücadelede önemli rol oynayan lider kadro içindeki bazı asker ve sivil aydınların muhalefeti, özellikle cumhuriyetin ilanı ile birlikte açığa çıkmıştır. Karabekir, Cebesoy, Rauf Bey gibi muhaliflerin 1924'ta kurdukları parti Mustafa Kemal Paşa'nın radikal reformlar projesine karşı, daha tedrici ve evrimsel bir değişimi ve daha liberal politikaları savunuyordu. Milli Mücadelenin askeri lider kadrosunun önemli isimlerini içinde barındırdığından bu muhalefet partisi CHP tarafından daha tehlikeli görülmüş, 1925 yılında Şeyh Sait isyanıla ilişkili gösterilerek kapatılmıştır. Bununla, tek-parti rejiminin konsolidasyon süreci tamamlanmış oldu (Özbudun, 2011: 78; Zürcher, 2005: 9; Kayalı, 2009: 43).

\section{Sonuç}

Milli Mücadele dönemi milliyetçilik düşüncesi ile birlikte, milli egemenlik ilkesinin de Türkiye'de yaygınlaştı̆̆ı yıllardır. Bunda sarayın ve İstanbul hükümetlerinin işgaller karşısındaki teslimiyetçi hatta işbirlikçi tutumlarının etkisi yadsınamaz. Kurtuluş Savaşı'nın başından itibaren adım adım gelişen halk egemenliği ideali, zaferden bir yıl sonra doğal olarak cumhuriyet ile sonuçlanmıştır. Mustafa Kemal Paşa meclis hükümeti usulünün cumhuriyete evrileceğini gördüğü ve bunu planladığı halde 1923 yılı Eylül ayı ortalarına kadar, kendi ifadesiyle bunu milli bir sır olarak saklamıştır.

Cumhuriyet, ilan tarihi ve rejim olarak niteliği açısından İstanbul basını ve Milli Mücadele yıllarında Atatürk ile birlikte önder kadro içinde yer alan bazı asker ve sivil yönetici ve aydınlar tarafından tepki ile karşılanmıştır. Bu muhalefetin nedeni şahsi kıskançlık ve farklı bir rejim talebinden çok, siyasal sistemin demokrasi ekseninden kayması endişesiydi. Muhalefete göre Mustafa Kemal Paşa, önceki meclis hükümeti sistemine göre cumhuriyet ile birlikte daha geniş yetkilerle donatılmıştı. Bu yetki yoğunlaşması rejimi ve cumhurbaşkanını otoriterleşmeye götürecekti. Gazi ise yalnız kendisinin başarabileceğine inandığı inkılapları yapabilmek için çok geniş yetkilerle donatılmış bir devlet başkanlığını ve muhalefetsiz bir meclisi zorunlu görüyordu. Rauf Bey, Karabekir ve Ali Fuat Paşanın başını çektiği muhalefet de milli egemenliği tam anlamıla sağlayan bir rejimden, demokratik cumhuriyetten yanaydılar. Atatürk ise en azından inkılapları gerçekleştirip, milli kalkınmayı yoluna koyana kadar devrimci-otoriter cumhuriyet çizgisini takip edecektir. Cumhuriyetle birlikte kurulan tek-parti rejiminin otoriter hatta bazı yönleriyle Atatürk'ün de ifade ettiği gibi totaliter bir diktatörlüğe dönüşme ihtimali rejimin mimarlarını rahatsız etmiştir (Okyar, 1980: 393). Rejimi bu olumsuz niteliğinden kurtarıp demokrasiye geçiş için yapılan denemeler başarısızlıkla sonuçlanmıştır. Başta Atatürk olmak üzere tek-parti rejimini kuranlar sürekli batı demokrasilerine öykünmüşlerdir. Bu kadro bir siyasal sistem olarak demokrasi konusunda ikircikli bir tutum içinde olmuştur. Sonuç olarak demokrasi konusunda rejimin mimarlarının gösterdiği bu mütereddit tavır en azından Türkiye'nin çok partili hayata geçişini geciktirmiştir. 


\section{Kaynakça}

\section{Temel Başvuru Kaynakları}

Atatürk, Nutuk, C.I-II, Türk Devrim Tarihi Enstitüsü Yay., Ankara 1970.

Atatürk'ün Söyleve ve Demeçleri, C.I-III, Atatürk Araştırma Merkezi Yay., Ankara 1997.

Öztürk, Kazım, Türk Parlamento Tarihi, TBMM II. Dönem, TBMM Yay., Ankara 1989.

Resmi Gazete, 9.11.1982, Sayı: 17863.

Türkiye Büyük Millet Meclisi Zabıt Ceridesi (TBMM ZC), Devre I-II, TBMM Matbaası, Ankara 1959.

\section{Gazeteler}

Hâkimiyet-i Milliye, (1.9.1923-30.11.1923).

İkdam, (1.9.1923-30.11.1923).

Tevhid-i Efkar, (1.9.1923-30.11.1923).

Tanin, (15.9.1923-30.11.1923).

Vatan, (20.9.1923-30.11.1923).

\section{Kitap ve Makaleler}

Abadan, Yavuz, Türk Inkılap Tarihine Giriş, Ajans Türk Matbaası, Ankara 1960.

Albayrak, Mustafa, Atatürk ve Türkiye Cumhuriyeti'nin Tarihsel Gelişimi, Atatürk Araştırma Merkezi Yay., Ankara 2010.

Atay, Falih Rıfkı, Çankaya, Pozitif Yay., İstanbul, 2010.

Aybars, Ergün, İstiklal Mahkemeleri 1920-1927, C.I-II, İleri Kitabevi, İzmir 1995.

Aydemir, Şevket Süreyya, Tek Adam Mustafa Kemal 1922-1938, C. III, Remzi Kitabevi, İstanbul 2011.

Başgil, Ali Fuat,Esas Teşkilat Hukuku, Baha Matbaası, İstanbul 1960.

Cebesoy, Ali Fuat, Siyasi Hatıralar, C. II, Temel Yay., İstanbul 2002.

Demirel, Ahmet, Birinci Meclis'te Muhalefet İkinci Grup, İletişim Yay., İstanbul 2003.

Duverger, Maurice, Siyasi Partiler, Çev: Ergun Özbudun, Bilgi Yayınevi, İstanbul 1974.

Ebuzziyazade Velid, “Cumhuriyet Bahsi Tavazzuh Ediyor mu?” Tevhid-i Efkar, 18.10.1923.

Ebuzziyazade Velid, “Cumhuriyet, Hâkimiyeti Milliye Esası İle Kabil-i Telif Değildir”, Tevhidi Efkar, 26.9.1923.

Ekincikli, Mustafa, “Türk Demokrasi Kültürünün Gelişim Sürecinde Terakkiperver Cumhuriyet Fırkası'nın Kuruluşu", Akademik Bakış, C. 6, Sayı: 11, Kış 2012, s. 151-163.

Eroğlu, Hamza, Atatürk ve Cumhuriyet, Atatürk Araştırma Merkezi Yay., Ankara 2014.

Goloğlu, Mahmut, Türkiye Cumhuriyeti 1923, İş Bankası Yay., İstanbul 2011.

Gözler, Kemal, "Hukuk Açısından Monarşi ve Cumhuriyet Kavramlarının Tanımı Sorunu”, AÜSBF Dergisi, 54-1, 1999, s. 52-62. 
Gözler, Kemal, Devlet Başkanları Bir Karşılaştırmalı Anayasa Hukuku İncelemesi, Ekin Kitabevi Yay. Bursa 2001.

Güner, Zekai, “Atatürk Cumhuriyet ve Demokrasi”, ZKÜ Sosyal Bilimler Dergisi, Cilt 2, Sayı 3, 2006, ss. 41-51.

Hüseyin Cahit, “Yaşasın Cumhuriyet”, Tanin, 31.10.1923.

İlgürel, Mücteba, Milli Mücadelede Balıkesir Kongreleri, Atatürk Araştırma Merkezi Yay., İstanbul 1999.

İnan, Afet, Medeni Bilgiler ve Mustafa Kemal Atatürk'ün Elyazıları, Atatürk Araştırma Merkezi Yayınları, Ankara 2000.

Kansu, Mazhar Müfit, Erzurum'dan Ölümüne Kadar Atatürk'le Beraber, C.I, TTK Yay. Ankara 1997.

Karabekir, Kazım, Paşalar Kavgası, Emre Yay., İstanbul 1991.

Karal, Enver Ziya, “Atatürk ve Cumhuriyetin Duyurulması”, Türk Dili, Kasım 1974, C: XXX, S: 278, s. $833-845$.

Karal, Enver Ziya, Atatürk'ten Düşünceler, MEB Yay., İstanbul 1981.

Karal, Enver Ziya, Türkiye Cumhuriyeti Tarihi 1918-1965, Türk Tarih Kurumu Yay., Ankara 1981.

Kayalı, Kurtuluş, Ordu ve Siyaset, 27 Mayıs-12 Mart, İletişim Yay., İstanbul 2009.

Kinross, Lord, Bir Milletin Yeniden Doğuşu, Atatürk, Çev: Necdet Sander, Sander Kitabevi, İstanbul 1966.

Konukçu, Enver, Alaşehir Kongresi, Atatürk Araştırma Merkezi Yay., Ankara 2000.

Mango, Andrew, Atatürk, Çev: Füsun Doruker, Remzi Kitabevi, İstanbul 2006.

Montesquieu, Charles-Louis de Secondat, Kanunların Ruhu Üzerine, Çev: Fehmi Baldaş, Hiperlink Yay., İstanbul 2011.

Okyar, Fethi, Üç Devirde Bir Adam, Tercüman Yay., İstanbul 1980.

Orbay, Rauf, Siyasi Hatıralar, Örgün Yayınevi, İstanbul 2003.

Özbudun, Ergun, 1921 Anayasası, Atatürk Araştırma Merkezi Yay., Ankara 2008.

Özbudun, Ergun, Otoriter Rejimler, Seçimsel Demokrasiler ve Türkiye, İstanbul Bilgi Üniversitesi Yay., İstanbul 2011.

Özkaya, Yücel, “Türk Basınında Cumhuriyetin İlanının Öncesi ve Sonrası”, Ankara Üniversitesi Türk Inkılap Tarihi Enstitüsü Atatürk Yolu Dergisi, Cilt: 3 Say1: 11, 1993, s. 279-310.

Rousseau, J.J., Toplum Sözleşmesi, Çev: Vedat Günyol, İş Bankası Yay., İstanbul 2006.

Soyak, Hasan Rıza, Atatürk'ten Hatıralar, C.I, YKB Yay., İstanbul 1973.

Şimşir, Bilal N., Ingiliz Belgelerinde Atatürk, C.I, TTK Yay., Ankara 1974.

Tanör, Bülent, "Yerel Kongrelerde Millî Egemenlik Düşüncesi", 9. Milli Egemenlik Sempozyumu, Yerel Kongrelerden Milli Egemenliğe, Balıkesir, 22 Nisan 1994, TBMM Kültür, Sanat ve Yayın Kurulu Yay., İstanbul 1996, ss. 90-96. 
Tanör, Bülent, Kuruluş, Kurtuluş, Cumhuriyet Kitapları, İstanbul 2009.

Tanör, Bülent, Osmanlı-Türk Anayasal Gelişmeleri, Yapı Kredi Yay., İstanbul 2012.

Toker, Metin, Demokrasimizin İsmet Paşa'lı Yılları: Tek Partiden Çok Partiye 1944-1950, Bilgi Yayınevi, İstanbul 1990.

Tunaya, Tarık Zafer, Türkiye'de Siyasal Gelişmeler 1876-1938, C.II, İstanbul Bilgi Üniversitesi Yay., İstanbul 2009.

Tunçay, Mete, Türkiye Cumhuriyeti'nde Tek Parti Yönetimi'nin Kurulması (1923-1931), Yurt Yay., Ankara 1981.

Tunçay, Mete, Türkiye'de Sol Akımlar, Bilgi Yay., Ankara 1978.

Turan, Şerafettin, "Millî Egemenlik Kavramının Türk Düşün Hayatına Girmesi ve Yerel Kongrelere Yansıması", 9. Milli Egemenlik Sempozyumu, Yerel Kongrelerden Milli Egemenliğe, Balıkesir, 22 Nisan 1994, TBMM Kültür, Sanat ve Yayın Kurulu Yay., İstanbul 1996, ss. 105115.

Türk Hukuk Lügatı, Maarif Vekâleti Yayını, Ankara 1944.

Yalman, Ahmet Emin, Yakın Tarihte Gördüklerim ve Geçirdiklerim, C. II, Yay. Haz. Erol Şadi Erdinç, Pera Yay., İstanbul 1997. 